\title{
The effect of extended post-mortem ageing on the Warner-Brazler shear force of longissimus thoracis from beef heifers from two sire breeds, slaughtered at 20 or 25 mo of age
}

\author{
A.P. Moloney ${ }^{1 \dagger}$, B. Picard ${ }^{2}$, L. Moran ${ }^{3, *}$ \\ ${ }^{1}$ Teagasc, Animal \& Grassland Research and Innovation Centre, Grange, Dunsany, Co. Meath, Ireland \\ IINRAE, Université Clermont Auvergne, VetAgro Sup, UMR Herbivores, F-63122 Saint-Genès-Champanelle, France \\ ${ }^{3}$ Teagasc, Food Research Centre, Ashtown, Dublin 15, Ireland \\ 'Present address: Lascaray Research Centre, University of the Basque Country, Miguel de Unamuno 3, 01006 Vitoria-Gasteiz, Spain
}

Abstract

The effects on tenderness of extended ageing of longissimus thoracis (LT, striploin) muscle that differed in structure and composition were examined. Spring-born Angus $\times$ Holstein-Friesian heifers $(n=48)$ and Belgian Blue $\times$ Holstein-Friesian heifers $(n=48)$ were slaughtered, within sire breed, at 20 or 25 mo of age. Approximately $48 h$ post-mortem, $L T$ steaks $(2.5 \mathrm{~cm})$ were removed, and either stored at $-20^{\circ} \mathrm{C}$ for chemical analysis or vacuum-packed, stored at $2^{\circ} \mathrm{C}$ for 7,14 or $28 \mathrm{~d}$ post-mortem and then at $-20^{\circ} \mathrm{C}$ pending Warner-Bratzler shear force (WBSF) analysis. Muscle from Angus-sired heifers had higher $(P<0.001)$ intramuscular fat $(I M F)$ concentration, lower $(P<0.001)$ proportion of type IIX muscle fibres and higher $(P<0.001)$ proportion of type IIA and type I muscle fibres compared to muscle from Belgian Blue-sired heifers. Collagen characteristics did not differ between sire breeds. Later slaughter increased $(P<0.001)$ IMF concentration and decreased $(P<0.001)$ total and insoluble concentrations and collagen solubility. There were no interactions between the main effects for WBSF and no difference between sire breeds. Later slaughter and increasing the duration of ageing decreased $(P<0.05)$ WBSF. Based on threshold WBSF values in the literature, all samples would be considered tender $(<39 \mathrm{~N})$ after $7 \mathrm{~d}$ ageing. Untrained consumers are likely to detect the decrease in WBSF from 7 to $14 \mathrm{~d}$ ageing but not due to further ageing. Within the production system examined and based on WBSF data, extending LT ageing to $28 \mathrm{~d}$ is not necessary to ensure consumer satisfaction.

Keywords

Beef $\bullet$ breed $\bullet$ instrumental texture $\cdot$ wet ageing

\section{Introduction}

Tenderness is generally considered the major influence on consumer satisfaction when eating beef (Miller et al., 2001). Post-mortem proteolysis results in the degradation of myofibrillar and cytoskeletal proteins which enhances beef tenderness (Ouali et al., 2006). This process, termed maturation or ageing, most commonly involves removal of individual muscles from the carcass, vacuum-packaging (wet ageing) and storage at $2-4^{\circ} \mathrm{C}$. While it is accepted that the time taken to reach a final tenderness endpoint is muscle dependent and that the rate of tenderisation decreases as ageing proceeds, the influence of production factors on tenderness evolution is unclear. Nevertheless, an ageing period is included in many "quality" beef specifications. In the United Kingdom (UK), to comply with a quality standard specification, "primals used for frying, roasting and grilling must be subject to a minimum $14 \mathrm{~d}$ maturation (from slaughter to the final consumer)" (EBLEX,
2012). In the United States (US), the earlier recommendation was for longissimus thoracis (LT) (commercial name = striploin) to be aged for at least $14 \mathrm{~d}$ (Mies et al., 1998). More recently, Gruber et al. (2006) concluded that post-mortem ageing should be managed with respect to US Department of Agriculture carcass grade with striploins from carcasses that graded "upper two-thirds Choice" achieving 95\% of the ageing response in $14 \mathrm{~d}$ compared to $66 \%$ for striploins from carcasses that are graded "Select". In Australia, all beef that has the Meat Standards Australia (MSA) label is aged for a minimum of $5 \mathrm{~d}$ (MLA, 2018). However, the MSA grading model predicts little increase in striploin quality score, of which tenderness represents $40 \%$, beyond $14 \mathrm{~d}$. Recently in Ireland there has been a move towards extended ageing of up to $30 \mathrm{~d}$ for striploin, particularly for "premium" branded products (Appendix 1). This is based presumably on a perception that 
this results in enhanced quality due to an increase, at least in part, in tenderness. From a commercial perspective, the cost incurred in extended ageing must be judged against the additional increase in tenderness or overall palatability. There is a paucity of information as to whether extended ageing of striploin from cattle within Irish beef production systems significantly, either statistically or commercially, increases tenderness. Therefore, the objective of this study was to determine the interaction between modifications within one typical heifer beef production system (Teagasc, 2015) and post-mortem ageing to $28 \mathrm{~d}$ on the tenderness, measured instrumentally as toughness, of striploin muscle.

\section{Materials and methods}

\section{Experimental design and animal management}

The study was carried out under license from the Irish Government Department of Health and Children and all procedures used complied with national regulations concerning experimentation on farm animals. Spring-born early-maturing sired (Aberdeen Angus) $\times$ Holstein-Friesian heifers (AAH, $n=48)$ and late-maturing sired (Belgian Blue) $\times$ Holstein-Friesian heifers $(\mathrm{BBH}, n=48)$ were reared from 4 mo of age according to the heifer grass-based dairy calf to beef blueprint described by Keane \& Drennan (2008). Within breed, the animals were blocked on bodyweight and within block assigned at random to early slaughter or late slaughter. The animals grazed a perennial ryegrass-dominant sward from July 1 , and were offered a daily allowance of grass dry matter (DM) sufficient to ensure a consumption of $2.5 \%$ bodyweight (assuming 75\% utilisation) for the whole group. They were housed on November 30 and offered unwilted grass silage ad libitum and $1.5 \mathrm{~kg}$ of concentrates per animal daily until turnout to pasture on April 1 when they again grazed a perennial ryegrass-dominant sward. At the end of October, animals previously assigned to early slaughter, were weighed on consecutive days, transported approximately $90 \mathrm{~km}$ to a commercial abattoir and slaughtered (Halal procedure, Farouk et al. (2014)) within 45 min of arrival. Carcasses were subjected to low voltage electrical stimulation (24 V, $30 \mathrm{~s}$ ). Animals previously assigned to late slaughter were housed on November 15 and offered unwilted grass silage ad libitum and $5.0 \mathrm{~kg}$ of concentrates per animal daily. At the end of March, they were weighed and slaughtered as described for animals slaughtered the previous October. Thus, within sire breed, there were two slaughter weight/age categories, that is, young/light and older/heavier.

\section{Carcass trait measurements and sample collection}

At $<45$ min post slaughter, a sample (ca $20 \mathrm{~g}$ ) of LT muscle tissue (from the $10^{\text {th }}$ rib position) was taken, snap frozen in liquid nitrogen and maintained at $-80^{\circ} \mathrm{C}$ for metabolic enzyme activity and fibre typing analyses. The carcasses were then weighed and graded for conformation (5-point scale, classes $E$ [highest] to $P$ [lowest], $E$ is 5) and fatness (5-point scale, scores 5 [highest] to 1 [lowest]) according to the EU Beef Carcass Classification Scheme (EC, 2006) and chilled under factory conditions. After approx. $24 \mathrm{~h}$ the right side of each carcass was cut at the $5^{\text {th }} / 6^{\text {th }}$ rib interface ("pistola" cut) and the LT muscle, between the $10^{\text {th }}$ and $13^{\text {th }}$ ribs (three rib striploin cut), was excised, vacuum packed, transferred to the Teagasc Food Research Centre, Ashtown, Dublin and stored at $2^{\circ} \mathrm{C}$ until approximately $48 \mathrm{~h}$ post-mortem.

\section{Muscle sampling and measurement}

At approximately $48 \mathrm{~h}$ post-mortem, the $\mathrm{pH}$ of the LT muscle $\left(\mathrm{pH}_{\mathrm{u}}\right)$ was measured by making a scalpel incision at the $10^{\text {th }}$ rib end and inserting a glass electrode (Model EC-2010-06; Amagruss Electrodes Ltd., Westport, Co. Mayo, Ireland) attached to a portable pH meter (Model no. 250A; Orion Research Inc., Boston, MA, USA) approximately $2.5 \mathrm{~cm}$ into the muscle. Five LT steaks of $2.5 \mathrm{~cm}$ thickness were then removed and vacuum-packed (Multivac ${ }^{\circledR}$, model A300/16; Multivac, Ltd., Swindon, UK). Two steaks were immediately frozen for chemical composition and collagen analysis, respectively. Three steaks were randomly assigned within carcass to storage at $2^{\circ} \mathrm{C}$ for 7,14 or $28 \mathrm{~d}$ post-mortem after which they were stored at $-20^{\circ} \mathrm{C}$.

Thawed samples of $\mathrm{LT}\left(4^{\circ} \mathrm{C}\right.$ overnight) with external fat and connective tissue removed were homogenized using a Robot coupe blender (R301 Ultra; Robot Coupe SA, Vincennes, France) and total intramuscular fat (IMF) content measured as described by Folch et al. (1957). Total and heat-soluble $\left(77^{\circ} \mathrm{C}, 65 \mathrm{~min}\right)$ collagen concentrations were determined by quantitative determination of hydroxyproline by a colorimetric reaction as described by Listrat \& Hocquette (2004).

The primary references for the analysis of the activity of glycolytic enzymes (phosphofructokinase [PFK, EC 2.7.1.11], lactate dehydrogenase [LDH, EC 1.1.1.27]) and oxidative enzymes (isocitrate dehydrogenase [ICDH, EC 1.1.1.42], citrate synthase [CS, EC 4.1.3.7] and cytochrome c oxidase [COX, EC 1.9.3.1]) were given in Moran et al. (2017). Muscle fibre types (Type I, IIA, IIX and IIB) were identified by separating myosin heavy chain $(\mathrm{MyHC})$ isoforms (MyHC I, Ila, IIx and Ilb) using high-resolution mini-gel electrophoresis as described by Picard et al. (2011).

For instrumental texture analysis, frozen vacuum-packed steaks were thawed in circulating water at $20^{\circ} \mathrm{C}$. External fat and connective tissue surrounding the muscle were removed and the steaks were conditioned for $15 \mathrm{~min}$ at $20^{\circ} \mathrm{C}$. The steaks were subsequently cooked in vacuum pack bags to an internal temperature of $70^{\circ} \mathrm{C}$, by immersing in a water bath (Model Y38; Grant Instruments Ltd. Royston, UK) at 
$72^{\circ} \mathrm{C}$. The internal temperature of the steaks was measured using a digital thermometer $(\mathrm{HI}$ 904; Hanna Instruments Ltd, Leighton Buzzard, Bedfordshire, UK). After cooking, the juices were removed, the steaks were cooled to room temperature and stored overnight in a closed bag at $4^{\circ} \mathrm{C}$, for subsequent Warner-Bratzler shear force (WBSF) analysis according to the procedure of Shackelford et al. (1994). Briefly, six cores $(1.25 \mathrm{~cm}$ diameter) parallel to the direction of the muscle fibres were obtained and sheared using an Instron Universal testing machine, model 5543 (Instron Corporation, High Wycombe, Buckinghamshire, UK) equipped with a WarnerBratzler shearing device. The crosshead speed was $5 \mathrm{~cm} / \mathrm{min}$. Instron Series IX Automated Materials Testing System software for Windows (Instron Corporation, High Wycombe, Buckinghamshire, UK) was employed in the analysis.

\section{Statistical analysis}

Animal, carcass and LT data (measured once), were subjected to analysis of variance using a model that had block, sire breed, slaughter time (early or late) and sire breed $x$ slaughter time as sources of variation. Warner-Bratzler shear force data were analysed as a randomised block, split-plot design with the sources of variation described already in the main plot and time of ageing and all time-related interactions in the sub-plot. Where significant effects were detected (F-test), means were separated using a Tukey's test. Data (measured once) were also subjected to multiple analysis of variance to calculate partial correlation coefficients $(p)$ from the error sum of squares and cross products matrix.

\section{Results}

Carcass and LT muscle characteristics are summarised in Table 1. There was no interaction between sire breed and slaughter time for any of the variables listed. Carcasses from $\mathrm{AAH}$ heifers were lighter, fatter (higher fat score) and had a poorer conformation $(P<0.001)$ than those from the $\mathrm{BBH}$ heifers. Later slaughter increased $(P<0.001)$ carcass weight and carcass fatness and improved carcass conformation. Muscle from AAH heifers had higher ( $P$ $<0.001)$ IMF content and lower $(P<0.05)$ LDH activity, whether expressed on a tissue or protein basis, compared to muscle from $\mathrm{BBH}$ heifers but other enzyme activities did not differ between sire breeds. Muscle from AAH heifers had a lower $(P<0.001)$ proportion of type IIX muscle fibres and a higher $(P<0.001)$ proportion of type IIA and type I muscle fibres compared to muscle from $\mathrm{BBH}$ heifers, but collagen characteristics did not differ between sire breeds. Later slaughter resulted in a higher muscle $\mathrm{pH}$ at $75 \mathrm{~min}$ and $48 \mathrm{~h}$ post-mortem, increased $(P<0.001)$ IMF concentration and the activities of LDH and PFK but decreased the activity of CS $(P<0.05)$, total and insoluble concentrations and collagen solubility.

The WBSF data are summarised in Table 2. There were no interactions between sire breed and slaughter time and there was no difference between sire breeds for WBSF. Later slaughter decreased $(P<0.05)$ WBSF as did the duration of ageing $(P<0.001)$ with both linear and quadratic terms being significant.

Partial correlation coefficients between characteristics of carcass or LT muscle and WBSF are shown in Table 3. The IMF content was negatively correlated with WBSF after $7(P<$ $0.05), 14(P<0.05)$ and $28(P<0.1)$ d ageing. ICDH activity, expressed on a protein basis, and LDH activity, expressed on a tissue basis, were negatively correlated $(P<0.05)$ with WBSF after $7 \mathrm{~d}$ ageing.

\section{Discussion}

The primary objective of this study was to determine the effects on tenderness of extended ageing of Irish striploin muscle. A larger project concerned with the enhancement of the nutritional quality of beef (Moloney et al., 2008) provided an opportunity to examine the influence of two important factors within beef production systems on the tenderness response to ageing. These factors were sire breed and time of slaughter, which were expected to change muscle structure and composition and possibly influence the tenderness response to extended ageing. It is recognised that within the production system chosen, slaughtering animals early, at a younger age, results in a lighter carcass and that the effects of slaughter time, age and carcass weight are therefore confounded. "Premium" striploins are often also branded as being from the progeny of early maturing breed sires such as Angus steers (Appendix 1). Comparison with the late maturing Belgian Blue breed was therefore of commercial interest. In this study, striploins were aged in vacuum sealed air-tight bags. This "wet" ageing is the most common commercial practise in Ireland. Extended ageing of intact joints in controlled atmospheric conditions termed "dry" ageing, is also used primarily for speciality products with a particular focus on flavour. This is considered a different post-mortem technology in the context of the present study and is not discussed further. An objective, standardised instrumental approach was used to directly measure toughness to allow comparison with the literature but also because of the practical constraints to carrying out trained sensory panel or consumer assessment of the large sample set used.

As expected, the sire breeds resulted in differences in carcass characteristics which are qualitatively similar to those reported for dairy origin steers sired by Angus or Belgian Blue bulls (Keady et al., 2017). The size of the difference between 
Table 1: Characteristics of the carcass and longissimus muscle from Angus and Belgian Blue sired Holstein-Friesian heifers slaughtered at 20 (early) or 25 (late) mo of age

\begin{tabular}{|c|c|c|c|c|c|c|c|}
\hline \multirow[b]{3}{*}{ Slaughter time (S) } & \multicolumn{4}{|c|}{ Sire breed (B) } & \multirow[b]{3}{*}{ sed } & & \\
\hline & \multicolumn{2}{|c|}{ Angus } & \multicolumn{2}{|c|}{ Belgian Blue } & & \multicolumn{2}{|c|}{ Significance $^{1}$} \\
\hline & Early & Late & Early & Late & & B & $S$ \\
\hline No of animals & 24 & 24 & 24 & 24 & & & \\
\hline Final weight (kg) & 472 & 588 & 478 & 603 & 10.1 & & *** \\
\hline Age (mo) & 20.1 & 24.7 & 20.1 & 24.6 & 0.09 & & $* * *$ \\
\hline Carcass (kg) & 234 & 298 & 250 & 321 & 5.91 & $* * *$ & *** \\
\hline Fat score ${ }^{2}$ & 3.4 & 4.2 & 2.5 & 3.6 & 0.19 & $* * *$ & *** \\
\hline Conformation score ${ }^{3}$ & 2.3 & 2.8 & 2.8 & 3.2 & 0.13 & $* * *$ & *** \\
\hline \multicolumn{8}{|l|}{ Longissimus muscle } \\
\hline Fat $(\mathrm{g} / \mathrm{kg})$ & 51.3 & 67.8 & 35.7 & 42.5 & 4.33 & $* * *$ & *** \\
\hline Protein $(\mathrm{g} / \mathrm{kg})$ & 212 & 212 & 212 & 212 & 4.91 & & \\
\hline \multicolumn{8}{|l|}{ Enzymatic activities } \\
\hline $\mathrm{ICDH}^{4}$ & 1.31 & 1.25 & 1.30 & 1.20 & 0.090 & & \\
\hline $\mathrm{ICDHp} \mathrm{p}^{5}$ & 6.20 & 5.91 & 6.14 & 5.67 & 0.437 & & \\
\hline $\mathrm{LDH}^{4}$ & 1120 & 1141 & 1155 & 1205 & 24.4 & ** & * \\
\hline $\mathrm{LDHp}^{5}$ & 5283 & 5412 & 5452 & 5700 & 134.5 & * & * \\
\hline $\mathrm{PFK}^{4}$ & 70.7 & 95.3 & 66.4 & 91.7 & 14.48 & & * \\
\hline $\mathrm{PFKp}^{5}$ & 335 & 455 & 313 & 434 & 68.9 & & * \\
\hline $\operatorname{cox}^{4}$ & 14.3 & 13.8 & 13.2 & 13.9 & 0.92 & & \\
\hline $\operatorname{coxp} p^{5}$ & 67.7 & 65.1 & 62.2 & 66.2 & 4.41 & & \\
\hline $\mathrm{CS}^{4}$ & 6.66 & 6.45 & 7.52 & 6.21 & 0.438 & & * \\
\hline $\mathrm{CSp}^{5}$ & 31.5 & 30.4 & 35.5 & 29.5 & 2.09 & & * \\
\hline $\mathrm{pH}(75 \mathrm{~min})$ & 6.13 & 6.50 & 6.18 & 6.55 & 0.56 & & * \\
\hline $\mathrm{pH}(48 \mathrm{~h})$ & 5.52 & 5.50 & 5.57 & 5.49 & 0.031 & & * \\
\hline \multicolumn{8}{|l|}{ Muscle fibre types (\%) } \\
\hline$\| x$ & 45.7 & 46.9 & 54.0 & 54.5 & 2.42 & $* * *$ & \\
\hline IIA & 34.8 & 35.0 & 29.7 & 30.1 & 2.20 & $* * *$ & \\
\hline 1 & 19.4 & 18.0 & 16.3 & 15.4 & 1.07 & $* * *$ & \\
\hline \multicolumn{8}{|l|}{ Collagen content } \\
\hline Insoluble collagen $(\% \mathrm{DM})^{6}$ & 2.38 & 1.81 & 2.35 & 2.05 & 0.130 & & $* * *$ \\
\hline Total collagen (\% DM) & 3.31 & 2.36 & 3.23 & 2.70 & 0.196 & & *** \\
\hline Collagen Solubility (\%) & 27.1 & 23.3 & 26.7 & 23.4 & 1.92 & & * \\
\hline
\end{tabular}

${ }^{1}$ There were no sire breed $\times$ slaughter weight interactions.

${ }^{2}$ Fat score; $5=$ fattest, $1=$ leanest.

${ }^{3}$ Conformation score; 5 = best, 1 = worst.

${ }^{4}$ Enzymatic activity expressed as $\mu \mathrm{mol} / \mathrm{min}$ per $\mathrm{g}$ of fresh muscle.

${ }^{5}$ Enzymatic activity expressed as $\mu \mathrm{mol} / \mathrm{min}$ per $\mathrm{g}$ of protein in muscle.

${ }^{6} \mathrm{DM}=$ dry matter.

sire breeds in LT IMF content across both studies reflects the different genders and experimental designs (59.6 vs. 39.1 in the present study and 74.5 vs. $36.4 \mathrm{~g} / \mathrm{kg}$ in Keady et al.
(2017) for Angus and Belgian Blue sires, respectively). The higher glycolytic enzyme activity (LDH) and the trend towards lower oxidative enzyme activities (ICDH and COX) for BBH 
Table 2: Warner Bratzler shear force (WBSF) of longissimus muscle from Angus and Belgian Blue sired Holstein-Friesian heifers slaughtered at 20 (early) or 25 (late) mo of age

\begin{tabular}{|c|c|c|c|c|c|c|}
\hline \multirow[b]{3}{*}{ Ageing (d) } & \multicolumn{6}{|c|}{ Sire breed $(B)$} \\
\hline & & \multicolumn{2}{|c|}{ Angus } & \multicolumn{2}{|c|}{ Belgian Blue } & \multirow[b]{2}{*}{ Mean $^{1}$} \\
\hline & & Early & Late & Early & Late & \\
\hline \multicolumn{7}{|l|}{ WBSF (N) } \\
\hline 7 & & 34.0 & 31.6 & 35.6 & 33.7 & $33.7^{\mathrm{a}}$ \\
\hline 14 & & 30.4 & 25.8 & 30.0 & 28.5 & $28.7^{b}$ \\
\hline 28 & & 26.2 & 22.9 & 27.0 & 23.6 & $24.9^{c}$ \\
\hline \multicolumn{7}{|l|}{ Significance } \\
\hline \multicolumn{7}{|l|}{ B } \\
\hline Slaughter time (S) & * & & & & & \\
\hline Days (D) & ${ }^{* * *}(\mathrm{~L}, \mathrm{Q})^{2}$ & & & & & \\
\hline \multicolumn{7}{|l|}{$B \times S$} \\
\hline \multicolumn{7}{|l|}{$B \times D$} \\
\hline \multicolumn{7}{|l|}{$S \times D$} \\
\hline \multicolumn{7}{|l|}{$B \times S \times D$} \\
\hline Sed $(B \times S \times D)$ & 1.92 & & & & & \\
\hline
\end{tabular}

${ }^{1}$ Means within a column with a different superscript differ significantly $(P<0.05)$.

${ }^{2} \mathrm{~L}$ and $\mathrm{Q}$ are linear and quadratic effects, respectively of duration of ageing.

heifers was similar to that seen in the comparison of early and late maturing bulls in Mezgebo et al. (2017). The difference in the distribution of muscle fibres between sire breeds was also similar to that reported by Mezgebo et al. (2017) and interpreted from the data reported by Maltin et al. (2001) for a comparison of purebred Angus and Charolais steers using a different methodology to measure muscle fibres. The lack of difference in collagen characteristics between sire breeds in the present study and also reported by Maltin et al. (1998) contrasts with that of Christensen et al. (2011) who reported lower collagen solubility for Angus bulls compared to Charolais bulls although total collagen concentration did not differ in that study. Similar to the present study, Cuvelier et al. (2006) found no difference in WBSF in meat from Angus (IMF concentration $=24.0 \mathrm{~g} / \mathrm{kg}$ ) and Belgian Blue bulls (IMF concentration $=6.5 \mathrm{~g} / \mathrm{kg}$ ) aged for $2 \mathrm{~d}$ and $8 \mathrm{~d}$, respectively. Chambaz et al. (2003) compared the WBSF of LT from Angus, Charolais, Limousin and Simmental steers slaughtered at a common IMF concentration $(32.5 \mathrm{~g} / \mathrm{kg})$ and found no difference. In contrast to the present study, Keady et al. (2017) reported lower WBSF for LT from Angus-sired steers than from Belgian Blue sired steers after $14 \mathrm{~d}$ ageing, which likely reflects the greater difference in IMF content in the two studies.

The effect of later slaughter (increasing slaughter age/weight) on IMF content and collagen solubility was as expected (Maltin et al., 1998; Mezgebo et al., 2019). The time interval in this study and that of Maltin et al. (1998) was not sufficient to alter the muscle fibre distribution seen in Mezgebo et al. (2019). The increase in glycolytic enzyme activity (LDH and PFK) and decrease in oxidative enzyme activity (CS) due to later slaughter which was not seen in Mezgebo et al. (2019) may reflect the higher energy density in the pre-slaughter diet of the heavier/older heifers. In support of this suggestion, when late maturing bulls were slaughtered at the same age from pasture or a high energy ration, carcass weight differed but the LT from the heavier animals had a more glycolytic and less oxidative metabolism (Moloney et al., 2017). The decrease in WBSF (increase in tenderness) with later slaughter in the present study is consistent with Lively et al. (2005) and McNamee et al. (2014) and is likely due to the increase in IMF content within the relatively narrow range in age. However, if animals were slaughtered at an older age, it is likely that the increase in IMF would not prevent an increase in WBSF due to a further decrease in collagen solubility as was seen by Mezgebo et al. (2019) in late maturing breed sired suckler bulls slaughtered between 19 and 24 mo of age. The age at which this transition would occur for heifers remains to be determined but slaughtering heifers older than 25 mo of age is unlikely to be commercially attractive.

In summary, the biochemical and structural characteristics of LT from the four categories of animal in this study were generally as expected based on the literature but the variation between the groups was very modest. 
Table 3: Partial correlation coefficients between characteristics of carcass or longissimus muscle and Warner Bratzler shear force (WBSF) after 7, 14 or $28 \mathrm{~d}$ ageing post mortem

\begin{tabular}{|c|c|c|c|}
\hline \multirow[b]{2}{*}{ Ageing (d) } & \multicolumn{3}{|c|}{ WBSF } \\
\hline & 7 & 14 & 28 \\
\hline Final weight $(\mathrm{kg})$ & -0.171 & -0.149 & -0.141 \\
\hline Age $(\mathrm{mo})$ & -0.137 & -0.112 & -0.037 \\
\hline Carcass (kg) & -0.106 & -0.110 & -0.071 \\
\hline Fat score $^{1}$ & 0.078 & 0.007 & 0.120 \\
\hline Conformation score ${ }^{2}$ & 0.144 & -0.000 & 0.016 \\
\hline \multicolumn{4}{|l|}{ Longissimus muscle } \\
\hline Fat $(\mathrm{g} / \mathrm{kg})$ & $-0.220^{*}$ & $-0.251^{*}$ & $-0.213^{+}$ \\
\hline Protein $(\mathrm{g} / \mathrm{kg})$ & $0.245^{\star}$ & 0.181 & 0.163 \\
\hline \multicolumn{4}{|l|}{ Enzymatic activities } \\
\hline $\mathrm{ICDH}^{3}$ & -0.126 & -0.035 & 0.059 \\
\hline $\mathrm{ICDHp}{ }^{4}$ & $-0.219^{*}$ & -0.098 & -0.003 \\
\hline $\mathrm{LDH}^{3}$ & $0.226^{*}$ & 0.074 & 0.035 \\
\hline $\mathrm{LDHp}^{4}$ & -0.053 & -0.122 & -0.140 \\
\hline $\mathrm{PFK}^{3}$ & 0.129 & 0.037 & 0.079 \\
\hline PFKp ${ }^{4}$ & 0.092 & 0.002 & 0.045 \\
\hline $\operatorname{cox}^{3}$ & 0.136 & 0.087 & 0.053 \\
\hline $\operatorname{coxp}{ }^{4}$ & 0.039 & 0.022 & -0.011 \\
\hline $\mathrm{CS}^{3}$ & 0.005 & -0.014 & 0.061 \\
\hline $\mathrm{CSp}^{4}$ & -0.083 & -0.076 & -0.010 \\
\hline \multicolumn{4}{|l|}{ Muscle fibre types (\%) } \\
\hline IIX & 0.060 & -0.017 & 0.017 \\
\hline IIA & -0.015 & 0.014 & -0.049 \\
\hline I & -0.108 & 0.008 & 0.061 \\
\hline \multicolumn{4}{|l|}{ Collagen content } \\
\hline Insoluble collagen $(\% \mathrm{DM})^{5}$ & 0.017 & 0.085 & -0.059 \\
\hline Total collagen (\% DM) & -0.020 & 0.103 & -0.046 \\
\hline Collagen solubility (\%) & -0.096 & 0.034 & 0.029 \\
\hline
\end{tabular}

${ }^{1}$ Fat score; 5 = fattest, 1 = leanest.

${ }^{2}$ Conformation Score; 5 = best, 1 = worst.

${ }^{3}$ Enzymatic activity expressed as $\mu \mathrm{mol} / \mathrm{min}$ per $\mathrm{g}$ of fresh muscle.

${ }^{4}$ Enzymatic activity expressed as $\mu \mathrm{mol} / \mathrm{min}$ per $\mathrm{g}$ of protein in muscle. ${ }^{5} \mathrm{DM}=$ dry matter.

It is generally accepted that ageing per se decreases muscle WBSF. The lack of an interaction between sire breed and slaughter time with ageing time for WSBF is indicative of a consistent pattern of ageing for the four animal type combinations examined in this study and reflects the small differences in muscle structure observed. The effect of ageing on muscle tenderness has been the subject of many studies and the findings are equivocal (below). The variation between studies likely reflects the animal/carcass type used, the ageing conditions, that is, whether as joint/partial carcass or individual muscle, whether vacuum packaged or not and the ageing temperature, the power of individual experiments and the instrument/shear force measurement protocol employed. Thus, Smith et al. (1978) observed no decrease in WBSF of LT aged up to $28 \mathrm{~d}$ compared to 11 d. Similarly, Jaborek et al. (2019) and Harris et al. (1992) concluded that compared to ageing for $14 \mathrm{~d}$, ageing for $28 \mathrm{~d}$ did not result in a significant decrease in WBSF of LT. In addition, ageing striploin for $42 \mathrm{~d}$ compared to $14 \mathrm{~d}$ (Colle et al., 2015) or for 35 d compared to 28 d (Laster et al., 2008; Juarez et al., 2010) did not decrease WBSF. In contrast, Jennings et al. (1987) observed a decrease in shear force of LT between 10 and $20 \mathrm{~d}$ ageing while Huff and Parrish (1993) observed a decrease in WBSF of LT between 14 and 28 d ageing (2.8 vs. $2.3 \mathrm{~kg}$ ) as did Adcock et al. (2015). No further decrease was observed in the latter study when ageing was extended to $42 \mathrm{~d}$. While Lepper-Blilie et al. (2016) reported a linear decrease in WBSF of striploin when aged up to $49 \mathrm{~d}$, WBSF at $28 \mathrm{~d}$ was lower than that at $14 \mathrm{~d}$ (2.48 vs. $2.80 \mathrm{~kg}$ ) but not subsequently. Across studies, the incremental decrease in WBSF with prolonged ageing (after $14 \mathrm{~d}$ ) is small. Gruber et al. (2006) examined the effects of post-mortem ageing for $2,4,6,10,14$ or $28 \mathrm{~d}$ on 17 individual muscles from two USDA grades of carcass. They reported that for the higher quality grade of carcass (upper two-thirds USDA Choice, marbling score 575), LT WBSF did not decrease beyond $21 \mathrm{~d}(3.96,3.66$ and $3.55 \mathrm{~kg}$ for 14, 21 and $28 \mathrm{~d}$ ageing, respectively). By contrast, for the lower grade carcasses (USDA Select, marbling score 351), LT WBSF decreased from 21 to $28 \mathrm{~d}$ ageing (5.02, 4.52 and $4.21 \mathrm{~kg}$ for 14,21 and $28 \mathrm{~d}$ ageing, respectively). Similarly, using the same procedure as in the present study, Moloney et al. (2018) showed that WBSF of LT from steers (IMF = $76 \mathrm{~g} / \mathrm{kg}$ ) did not decrease between 14 and $21 \mathrm{~d}$ ageing while WBSF of LT from bulls of a similar genotype (IMF $=43 \mathrm{~g} / \mathrm{kg}$ ) decreased by $4.8 \mathrm{~N}$. These data are consistent with the data from the present study, that is, LT with the higher IMF concentration had lower WBSF and on average, WBSF was lower after $28 \mathrm{~d}$ ageing compared to $14 \mathrm{~d}$. The small negative partial correlation supports the influence of IMF content on WBSF.

While the lower WBSF value for 28 compared to $14 \mathrm{~d}$ aged LT in the present study was statistically significant, the actual difference was small (3.72 N). Several studies have sought to interpret WBSF vales in the context of consumer acceptability and the ability of consumers to detect differences. Miller et al. (2001) reported that WBSF values of $<3.0(29.4 \mathrm{~N})$, $3.4(33.4 \mathrm{~N})$ and $4.0(39.2 \mathrm{~N})$ would result in 100, 99 and $94 \%$ US consumer satisfaction for beef tenderness. Similarly, 


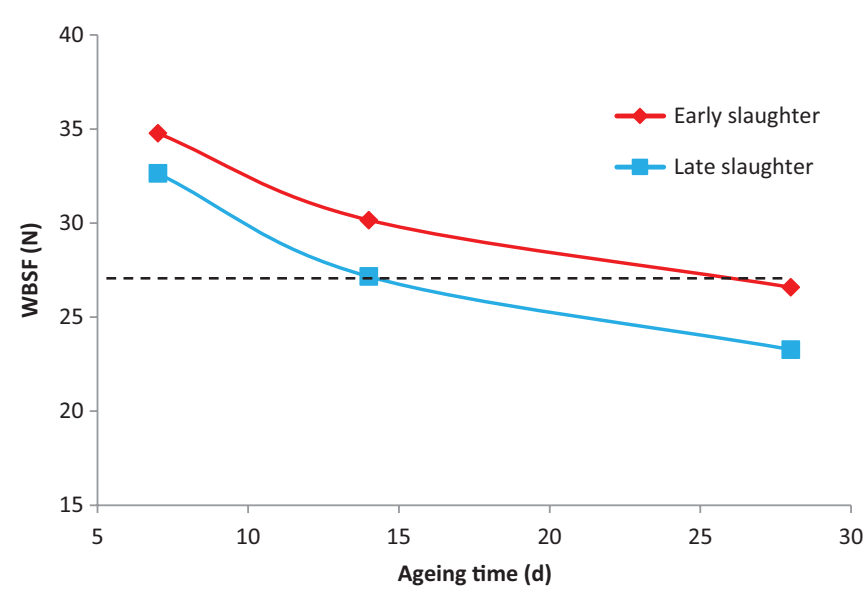

Figure 1. Warner Bratzler shear force (WBSF) during post-mortem ageing of longissimus muscle from heifers slaughtered at 20 (early) or 25 (late) mo of age.

Belew et al. (2003) concluded that "beef with WBSF values $<3.2 \mathrm{~kg}(31.4 \mathrm{~N})$ would be rated very tender by trained panellists irrespective of muscle source". Destefanis et al. (2008) indicated that European consumers would consider LT with a WBSF value $<42.87 \mathrm{~N}$ to be tender. Based on these data, on average all samples in the current study would be considered tender even after $7 \mathrm{~d}$ ageing. From the data of Miller et al. (2001) a difference in WBSF of approximately $4.9 \mathrm{~N}$ can be detected by a consumer. Therefore, untrained consumers are likely to detect the decrease in WBSF from 7 to $14 \mathrm{~d}$ ageing (5.48 and $4.62 \mathrm{~N}$ for LT from late and early slaughtered heifers, respectively) but not due to further ageing (3.88 and 3.57 N for LT from late and early slaughtered heifers, respectively). It is noteworthy that in the present study, WBSF of LT from carcasses from the later slaughtered heifers aged for $14 \mathrm{~d}$ was similar to the LT from carcasses from the early slaughtered heifers aged for $28 \mathrm{~d}$ (Figure 1) indicating that a particular WBSF target is influenced by both carcass type and the duration of ageing. In this regard, Lepper-Blilie et al. (2016), who examined the effect of extended ageing on both WSBF and sensory characteristics of striploin concluded that "while WBSF values declined linearly from day 14 to day 49 of ageing, economic and flavour attribute data suggest the small improvement in WBSF value beyond $21 \mathrm{~d}$ cannot be used to justify the extended ageing period". Similarly, Adcock et al. (2015) concluded that for Certified Angus muscle despite the decrease in WBSF from 14 to $28 \mathrm{~d}$ ageing, "consumers signified only minute differences (in sensory palatability) following $14 \mathrm{~d}$ of ageing".

It is concluded that within the production system examined in the present study, and based on WBSF data, extending LT ageing to $28 \mathrm{~d}$ is not necessary to ensure consumer satisfaction.

\section{Acknowledgements}

Financial support from the EU Project "ProsafeBeef" (FOOD-CT-2006-36241) is gratefully acknowledged. The assistance of Dr Didier Micol INRA (deceased) with muscle biochemical analysis and of Mr. V. McHugh Teagasc, with animal management is also gratefully acknowledged. The authors thank the management and staff at Meadow Meats, Rathdowney, Co. Laois, Ireland for their co-operation and assistance during slaughter and sample collection.

\section{References}

Adcock, L.A., Sawyer, J.T., Lambert, B.D., Jones, T.N., Ball, J.J., Wyatt, R.P. and Jackson, J. 2015. Aging implications on fresh muscle traits of Certified Angus Beef steaks. Journal of Animal Science 93: 5863-5872.

Belew, J.B., Brooks, J.C., McKenna, D.R. and Savell, J.W. 2003. Warner-Bratzler shear evaluations of 40 bovine muscles. Meat Science 64: 507-512.

Chambaz, A., Scheeder, M.R.L., Kreuzer, M. and Dufey, P.A. 2003. Meat quality of Angus, Simmental, Charolais and Limousin steers compared at the same intramuscular fat content. Meat Science 63: 491-500.

Christensen, M., Ertberg, P., Failla, S., Sanudo, C., Richardson, R.I., Nute, G.R., Olleta, J.L., Panea, B., Alberti, P., Juarez, M., Hocquette, J.F. and Williams, J.L. 2011. Relationship between collagen characteristics, lipid content and raw and cooked texture of meat from young bulls of fifteen European breeds. Meat Science 87: 61-65.

Colle, M.J., Richard, R.P., Killinger, K.M., Bohlscheid, J.C., Gray, A.R., Loucks, W.I., Day, R.N., Cochrane, A.S., Nasados, L.A. and Doumit, M.E. 2015. Influence of extended aging on beef quality characteristics and sensory perception of steaks from the gluteus medius and longissimus lumborum. Meat Science 110: 32-39.

Cuvelier, C., Clinquart, A., Hocquette, J.F., Cabaraux, J.F., Dufrasne, I., Istasse, L. and Hornick, J.-L. 2006. Comparison of composition and quality traits of meat from young finishing bulls from Belgian Blue, Limousin and Aberdeen Angus breeds. Meat Science 74: 522-531.

Destefanis, G., Brugiapaglia, A., Barge, M.T. and Dal Molin, E. 2008. Relationship between beef consumer tenderness perception and Warner-Bratzler shear force. Meat Science 78: 153-156.

EBLEX. 2012. "Quality Standard Mark Scheme for Beef and Lamb. Scheme Standard and Specifications". EBLEX, Warwickshire, UK.

EC. 2006. Council Regulation (EC) No 1183/2006 of 24 July 2006 concerning the Community scale for the classification of carcasses of adult bovine animals. Official Journal of the European Union 214: $1-6$. 
Farouk, M.M., Al-Mazeedi, H.M., Sabow, A.B., Bekhit, A.E.D., Adeyemi, K.D., Sazili, A.Q. and Ghani, A. 2014. Halal and kosher slaughter methods and meat quality: a review. Meat Science 98: 505-519.

Folch, J., Lees, M. and Sloane Stanley, G.H. 1957. A simple method for the isolation and purification of total lipids from animal tissues. Journal of Biological Chemistry 226: 497-509.

Gruber, S.L., Tatum, J.D., Scanga, J.A., Chapman, P.L., Smith, G.C. and Belk, K.E. 2006. Effect of postmortem ageing and USDA grade on Warner-Bratzler shear force values of seventeen individual beef muscles. Journal of Animal Science 84: 3387-3396.

Harris, L.L., Miller, R.K., Savell, J.W., Cross, H.R. and Ringer, L.J. 1992. Evaluation of the tenderness of beef top sirloin steaks. Journal of Food Science 57: 6-15.

Huff, E.J. and Parrish, F.C. 1993. Bovine longissimus tenderness as affected by post-mortem aging time, animal age and sex. Journal of Food Science 58: 713-716.

Jaborek, J.R., Zerby, H.N., Moeller, S.J., Fluharty, F.L. and Belling, A.E. 2019. Evaluation of feedlot performance, carcass characteristics, carcass retail cut distribution, Warner-Bratzler shear force, and fatty acid composition of purebred Jersey and crossbred Jersey steers. Translational Animal Science 3: 1475-1491.

Jennings, T.G., Berry, B.W. and Joseph, A.L. 1978. Influence of fat thickness, marbling and length of aging on beef palatability and shelf-life characteristics. Journal of Animal Science 46: 658-665.

Juarez, M., Larsen, I.L., Gibson, L.L., Robertson, W.M., Dugan, M.E.R., Aldai, N. and Aalhus, J.L. 2010. Extended ageing time and temperature effects on quality of sub-primal cuts of boxed beef. Canadian Journal of Animal Science 90: 361-370.

Keady, S.M., Waters, S., Hamill, R., Dunne, P., Keane, M.G., Richardson, R.I., Kenny, D.A. and Moloney, A.P. 2017. Compensatory growth in crossbred Aberdeen Angus and Belgian Blue steers: effects on the colour, shear force and sensory characteristics of longissimus muscle. Meat Science 125: 128-136.

Keane, M.G. and Drennan, M.J. 2008. A comparison of Friesian, Aberdeen Angus $\times$ Friesian and Belgian Blue $\times$ Friesian steers finished at pasture or indoors. Livestock Science 115: 268-278.

Laster, M.A., Smith, R.D., Nicholson, K.L., Nicholson, J.D.W., Miller, R.K., Griffin, D.B., Harris, K.B. and Savell, J.W. 2008. Dry versus wet ageing of beef: retail cutting yields and consumer sensory attribute evaluations of steaks from ribeyes, strip loins, and top sirloins from two quality grade groups. Meat Science $\mathbf{8 0}$ : 795-804.

Lepper-Blilie, A.N., Berg, E.P., Buchanan, D.S. and Berg, P.T. 2016. Effects of post-mortem aging time and type of aging on palatability of low marbled beef loins. Meat Science 112: 63-68.

Listrat, A. and Hocquette, J.F. 2004. Analytical limits of total and insoluble collagen content measurements and of type I and III collagen analysis by electrophoresis in bovine muscles. Meat Science 68: 127-136.

Lively, F.O., Keady, T.W.J., Moss, B.W., Patterson, D.C. and Kilpatrick, D.J. 2005. The effect of genotype, carcass weight and fat classification, and pelvic hanging technique on meat quality. Proceedings of the British Society of Animal Science, page 59.

Maltin, C.A, Sinclair, K.D., Warriss, P.D., Grant, C.M., Porter, A.D., Delday, M.I. and Warkup, C.C. 1998. The effects of age at slaughter, genotype and finishing system on the biochemical properties, muscle fibre type characteristics and eating quality of bull beef from suckled calves. Animal Science 66: 341-348.

Maltin, C.A., Lobley, G.E., Grant, C.M., Miller, L.A., Kyle, D.J., Horgan, G.W., Matthews, K.R. and Sinclair, K.D. 2001. Factors influencing beef eating quality. 1 . Effects of nutritional regime and genotype on muscle fibre characteristics. Animal Science 72: 279-287.

McNamee, A., Keane, M.G., Kenny, D.A., O'Riordan, E.G., Dunne, P.G. and Moloney, A.P. 2014. Colour of subcutaneous adipose tissue and colour and tenderness of the longissimus thoracis et lumborum muscle from Holstein-Friesian, Norwegian Red $\times$ Holstein-Friesian and Jersey $\times$ Holstein-Friesian cattle slaughtered at two live weights as bulls or steers. Agricultural and Food Science 23: 266-277.

Mezgebo, G.B., Monahan, F.J., McGee, M., O'Riordan, E.G., Picard, B., Richardson, R.I. and Moloney, A.P. 2017. Biochemical and organoleptic characteristics of muscle from early and late maturing bulls in different production systems. Animal 11: 1636-1644.

Mezgebo, G.B., Monahan, F.J., McGee, M., O’Riordan, E.G., Marren, D., Listrat, A., Picard, B., Richardson, R.I. and Moloney, A.P. 2019. Extending the grazing period for bulls, prior to finishing on a concentrate ration: composition, collagen structure and organoleptic characteristics of beef. Foods 8: 278.

Mies, P.D., Belk, K.E., Tatum, J.D. and Smith, G.C. 1998. "Effects of Post-Mortem Aging on Beef Tenderness, and Aging Guidelines to Maximize Tenderness of Different Beef Subprimal Cuts". Beef Program Report, Program in Meat Science, Colorado State University, Fort Collins, CO, USA.

Miller, M.F., Carr, M.A., Ramsey, C.B., Crockett, K.L. and Hoover, L.C. 2001. Consumer thresholds for establishing the value of beef tenderness. Journal of Animal Science 79: 3062-3068.

MLA. 2018. How ageing affects beef quality. In: "Tips and tools, Meat Standards Australia”. Meat \& Livestock Australia, Sydney, Australia, pages 31-32.

Moloney, A.P., Scollan, N.D. and Miles, L. 2008. Enrichment of n-3 fatty acids and conjugated linoleic acid in beef: ProSafeBeef. Nutrition Bulletin 33: 374-381.

Moloney, A.P., O'Riordan, E.G., McGee, M., Picard, B. and Moran, L. 2017. Grass-based suckler bull beef production: muscle colour and fibre composition. Proceedings 63rd International Congress on Meat Science and Technology, Cork, Ireland, pages 252-253.

Moloney, A.P., Prendiville, R.P., Allen, P., O'Sullivan, M.G., Kerry, J.P. and Moran, L. 2018. Colour and tenderness of muscles from Holstein-Friesian bulls (19 months) or steers (24 months): effect of carcass suspension. Proceedings 64th International Congress on Meat Science and Technology, Melbourne, Australia, page 6070.

Moran, L., O'Sullivan, M.G., Kerry, J.P., Picard, B., McGee, M., O'Riordan, E.G. and Moloney, A.P. 2017. Effect of a grazing period 
prior to finishing on a high concentrate diet on meat quality from bulls and steers. Meat Science 125: 76-83.

Ouali, A., Herrera-Mendez, C.H., Coulis, G., Becila, S., Boudjellal, A., Aubry, L. and Sentandreu, M.A. 2006. Revisiting the conversion of muscle into meat and the underlying mechanisms. Meat Science 74: 44-58.

Picard, B., Barboiron, C., Chadeyron, D. and Jurie, C. 2011. Protocol for high-resolution electrophoresis separation of myosin heavy chain isoforms in bovine skeletal muscle. Electrophoresis 32: 1804-1806.
Shackelford, S., Koohmaraie, M., Cundiff, L., Gregory, K., Rohrer, G. and Savell, J. 1994. Heritabilities and phenotypic and genetic correlations for bovine postrigor calpastatin activity, intramuscular fat content, Warner-Bratzler shear force, retail product yield, and growth rate. Journal of Animal Science 72: 857-863.

Smith, G.C., Culp, G.R. and Carpenter, Z.L. 1978. Postmortem aging of beef carcasses. Journal of Food Science 43: 823-826.

Teagasc. 2015. "Beef Production System Guidelines". Teagasc, OakPark, Carlow, Ireland.

Appendix 1: Declared aging time on packaged striploins in the major Irish retailers

\begin{tabular}{lcc}
\hline Retailer & Product name & Ageing time (d) \\
\hline Dunnes Stores & "Simply Best" Irish Angus Striploin & 28 \\
Dunnes Stores & Irish Beef Striploin Steaks & 21 \\
Tesco & "Tesco Finest" Irish Angus Striploin & 30 \\
Tesco & Irish Beef Striploin & 28 \\
Aldi & "Butchers Selection" Irish Matured Striploin \\
Aldi & Irish Beef Striploin & 30 \\
Aldi & Irish Black Angus Striploin & 28 \\
Lidl & "Deluxe" Irish Hereford Striploin \\
Lidl & Inisvale 100\% Irish Striploin \\
Lidl & Inisvale Irish Striploin \\
Supervalu & "Signature Tastes" Striploin & 28 \\
\hline
\end{tabular}

Survey carried out 6 and 7 July 2019. 